\title{
Pengaruh Religiostik, EWOM, Brand Image dan Attitude terhadap Purchase Intention
}

\author{
Lily Purwianti ${ }^{1}$ \\ ${ }^{1}$ Universitas Internasional Batam, lpurwianti@yahoo.com
}

\begin{abstract}
The growth of the cosmetics industry in Indonesia is very encouraging for competition between cosmetic manufacturers in Indonesia. The cosmetic competition from South Korea increases the competition to be very complex. Indonesia, which is most important for Islam, poses a different challenge for cosmetic producers so that the religiosity factor must be considered. With the spread of the internet around the world, interpersonal communication has been reshaped from traditional face-to-face communication to a more virtual way of communication called electronic word of mouth (E-WOM), where consumers have a great opportunity to share information about their consumption experiences and for investment advice on products and brands using social networking platforms and consumer review sites. This study aims to study whether religiosity, EWOM, brand image, and attitudes influence purchase intention. The research sample is the people of Batam city who see cosmetics from South Korea. The number of samples in this study was 320 respondents with a purposive sample technique. Structural Equation Modeling (SEM) based on Partial Least Square (PLS) was used in this study. The results of this study are that religiosity affects attitudes and purchase intentions, EWOM affects attitudes and purchase intentions, and attitudes that affect purchase intentions. Everything else from this study is that brand image does not affect purchase attitudes and intentions.
\end{abstract}

Keywords: religiostic, EWOM, brand image, attitude, purchase intention

\begin{abstract}
ABSTRAK
Pertumbuhan industri kosmetik di Indonesia yang sangat pesat mendorong terjadinya persaingan antar produsen kosmetik di Indonesia. Serbuan kosmetik asal Korea Selatan menambah persaingan menjadi sangat kompleks. Indonesia yang mayoritas beragama islam menjadi tantangan tersendiri bagi produsen kosmetik sehingga faktor religiostik harus diperhatikan. Dengan penyebaran internet di seluruh dunia, komunikasi antar pribadi dibentuk ulang dari komunikasi tatap muka tradisional hingga cara komunikasi yang lebih virtual yang disebut electronic word of mouth (E-WOM), di mana konsumen mendapat kesempatan bagus untuk berbagi informasi tentang pengalaman konsumsi konsumen dan untuk menyebarkan saran mengenai produk dan merek menggunakan platform jejaring sosial dan situs ulasan konsumen. Penelitian ini bertujuan untuk menganalisis apakah religiostik, EWOM, brand image dan attitude yang memengaruhi purchase intention. Sampel penelitian ini adalah masyarakat kota Batam yang mengetahui kosmetik asal korea selatan. Jumlah sampel dalam penelitian ini adalah 320 responden dengan teknik purposive sampel. Structural Equation Modeling (SEM) berbasis Partial Least Square (PLS) di gunakan dalam penelitian ini. Hasil pada penelitian ini adalah religiostik mempengaruhi attitude dan purchase intention, EWOM berpengaruh terhadap attitude dan purchase intention, dan attitude berpengaruh terhadap purchase intention. Temua lain dari penelitian ini adalah brand image tidak berpengaruh terhadap attitude dan purchase intention.
\end{abstract}

Kata Kunci : religiostik, EWOM, brand image, attitude, purchase intention

Naskah diterima: 09-11-2020, direvisi: 11-01-2021, diterbitkan: 01-04-2021

\section{PENDAHULUAN}

Pertumbuhan industri kosmetik di Indonesia selama tahun 2019 sebesar $9 \%$ dan pada tahun 2020 ditargetkan pertumbuhannya lebih dari $9 \%$. Pasar kecantikan dan perawatan diri di Indonesia diperkirakan mencapai US\$ 6.03 miliar pada tahun 2019 dan diperkirakan pada tahun 2022 sebesar US\$ 8,46 miliar (Kemenparin, 2020). Sehingga pasar kosmetik merupakan sektor andalan di Rencana Induk Pembangunan Industri Nasional (RIPIN) tahun 2015-2035 (Kemenperin, 2018).

Berdasarkan Survei dari survei ZAP Beauty Index 2020 terhadap mengungkapkan bahwa negara Korea Selatan yang masih menjadi negara dengan produk skincare yang diminati oleh wanita Indonesia $(57,6 \%)$, diikuti Indonesia $(37,4 \%)$ dan Jepang $(22,7 \%)$ (ZAP, 2020). Potensi 
ini didukung juga oleh jumlah penduduk Indonesia sebanyak 268.583.016 dan mayoritas beragama islam sebanyak $82,7 \%$ (Indonesia. go.id, n.d.). Mayoritas penduduk yang beragama islam membuat tantangan sendiri bagi kosmetik korea untuk dapat diterima di pasar Indonesia. Sebagai umat Islam dituntut untuk berperilaku sesuai dengan tuntutan agama, salah satunya dengan mengkonsumsi produk halal. Oleh karena itu akan menciptakan peluang besar untuk menjadikan umat muslim sebagai target pasar produk kosmetik halal.

Kosmetik halal dapat diartikan sebagai kosmetik yang tidak mengandung bahan yang dilarang oleh hukum Islam dan diproses sesuai dengan hukum Islam seperti sertifikat halal Majelis Ulama Indonesia (MUI) dan pengawasan BPOM yang di dalamnya terdapat unsur jaminan bahwa produk tersebut halal. Umat Muslim di Indonesia pada umumnya telah mengkonsumsi makanan dan minuman halal sesuai dengan syariat Islam, namun masih belum banyak yang mengkonsumsi produk kosmetik halal. Dari studi pendahuluan ditemukan bahwa dari 30 milenial wanita muslim, hanya 12 diantaranya yang mengkonsumsi produk kosmetik halal (Handriana et al., 2020). Dengan demikian, kurang dari setengahnya yang memperhatikan kehalalan produk kosmetik yang konsumen beli.

Berdasarkan kondisi Indonesia yang mempunyai penduduk mayoritas muslim maka faktor religiostik memegang peranan penting dalam perilaku seseorang karena dianggap sebagai salah satu faktor yang menentukan perilaku individu dan dianggap sebagai variabel fundamental yang berpengaruh terhadap sikap dan perilaku (Mukhtar \& Butt, 2012). Hal ini berarti bahwa religiostik sangat memengaruhi attitude konsumen terhadap suatu poduk (Amalia, Sosianika, \& Suhartanto, 2020). Selain religiostik terdapat faktor lain yang memengaruhi attitude adalah brand image. Merek merupakan hal yang diperhatikan dalam berperilaku terhadap produk halal. Brand image yang baik akan mengarahkan konsumen pada produk halal. Brand image memiliki dampak terhadap sikap konsumen terhadap produk (Handriana et al., 2020).

Dengan penyebaran internet di seluruh dunia, komunikasi antar pribadi telah sangat dibentuk ulang dari komunikasi tatap muka tradisional hingga cara komunikasi yang lebih virtual yang disebut electronic word of mouth (EWOM), di mana konsumen mendapat kesempatan bagus untuk berbagi informasi tentang pengalaman konsumsi konsumen dan untuk menyebarkan saran mengenai produk dan merek menggunakan platform jejaring sosial dan situs ulasan konsumen (Elseidi \& El-baz, 2016). E-WOM merupakan pernyataan negative maupun positif dari konsumen tentang produk dan dapat diakses oleh orang banyak melalui internet (Kumar, 2017). Pada tahap pencarian informasi, referensi konsumen online dapat diperoleh dari berbagai sumber seperti jejaring media sosial. Semakin terkenal situs jejaring sosial akan memberikan dampak yang semakin besar. Seiring berkembangnya teknologi, EWOM tidak terbatas hanya pernyataan pelanggan sendiri akan tetapi mencakup posting dari sumber lain, dipostkan ulang oleh calon konsumen, konsumen saat ini atau sebelumnya tentang suatu produk $(\mathrm{Hu}, \mathrm{Ha}$, Mo, \& Xu, 2014). Sehingga $E-W O M$ juga bisa mempengaruhi attitude konsumen terhadap suatu produk (Kumar, 2017).

Penelitian tentang produk halal sudah banyak dilakukan dalam beberapa tahun terakhir. Sebagian besar terkait dengan produk makanan dan minuman halal (Ahmadova \& Aliyev, 2020; Akın \& Okumuş, 2020; Ali, Sherwani, Ali, Ali, \& Sherwani, 2020; Amalia et al., 2020; Bashir, 2019; Hanafiah \& Hamdan, 2020; Iranmanesh, Mirzaei, Parvin Hosseini, \& Zailani, 2019; Khan, Akhtar, Ansari, \& Dhamija, 2020; Muflih \& Juliana, 2020; Muhamed, Ab Rahman, Mohd Hamzah, Che Mohd Zain, \& Zailani, 2019; Wibowo, Permana, Hanafiah, Ahmad, \& Ting, 2020) Penelitian tentang produk kosmetik halal (Haque, Anwar, Tarofder, Ahmad, \& Sharif, 2018; Karoui \& Khemakhem, 2019; Khan, Sarwar, \& Tan, 2020; Suhartanto et al., 2020; Suparno, 2020). Akan tetapi belum ada yang mengkaji lebih spesifik tentang produk kosmetik halal, penelitian ini mencoba melihat secara spesifik tentang produk kosmetik asal Korea Selatan.

Banyak penelitian telah mengadopsi Theory of planned behaviour (TPB) untuk mengukur niat membeli halal di kalangan konsumen Muslim (Amalia et al., 2020; Hanafiah \& Hamdan, 2020; Handriana et al., 2020; Iranmanesh et al., 2019; Jumani \& Sukhabot, 2020; Memon, Azhar, Haque, \& Bhutto, 2019; Ngah, Gabarre, Eneizan, \& Asri, 2020; Wibowo et al., 2020). Pada penelitian ini mengambil sisi yang berbeda yaitu memasukkan E-WOM karena EWOM ini masih jarang diteliti untuk mengukur niat membeli produk kosmetik halal asal Korea . Media elektronik yang berkembang merupakan sumber informasi yang kuat dan handal (Shukla, 2011), pengaruh interaksi interpersonal (eWOM) terhadap keputusan pembelian meningkat secara signifikan (López \& Sicilia, 2014). Ulasan online merupakan informan dan memberikan rekomendasi yang kuat akan memengaruhi niat membeli dan pembelian actual (Kumar, 2017). Sedangkan mengacu pada WOM yang diberikan di berbagai saluran media sosial, bukan hanya kualitas tetapi juga kuantitas EWOM yang 
memengaruhi keputusan pembelian konsumen (Lin \& Lu, 2011).

Penelitian ini untuk menganalisis apakah religiostik, EWOM, brand image dan attitude yang mempengaruhi purchase intention pada pembelian kosmetik di kota Batam.

\section{KAJIAN LITERATUR}

\section{Purchase intention}

Purchase mengacu pada keinginan kesediaan seseorang untuk membeli sesuatu yang menambah nilai bagi konsumen sehingga purchase intention adalah pemikiran, keinginan dan minat konsumen terhadap suatu produk yang akan mengarah pada tindakan untuk membeli produk yang diinformasikan (Khan, Sarwar, et al., 2020). Pengukuran niat berperilaku dapat dengan mudah dicapai dengan menanyakan pernyataan subjektif kepada konsumen mengenai perilaku mereka di masa depan. Mengukur niat untuk berperilaku akan menjadi pendekatan terbaik untuk memprediksi perilaku pembelian di masa depan. Salah satu cerminan niat perilaku konsumen adalah niat beli atau niat membeli. Purchase intention adalah rencana sadar konsumen untuk berusaha membeli suatu produk. Intensi untuk membeli prosedur untuk memeriksa dan memprediksi perilaku konsumen dalam perhatian mereka pada merek tertentu dan kemauan mereka untuk melakukan pembelian(Garg \& Joshi, 2018) .

Niat membeli merupakan janji tersirat pada diri sendiri untuk membeli produk. Mengetahui purchase intention adalah yang terpenting dikarenakan menggambarkan kesan pelanggan. Citra merek, sikap merek, pengetahuan tentang atribut, merek, dan loyalitas merek adalah merupakan dimensi merek yang menjadi kecenderungan niat membeli (Tariq, Rafay Nawaz, Nawaz, \& Butt, 2013). Fungsi-fungsi ini memiliki pengaruh yang kuat terhadap niat membeli pelanggan. Purchase intention diklasifikasikan sebagai proses kompleks yang biasanya terkait dengan perilaku, persepsi, dan sikap mereka (Mirabi, Akbariyeh, \& Tahmasebifard, 2015). Niat membeli mengacu pada keinginan kesediaan seseorang untuk membeli sesuatu yang menambah nilai bagi mereka. Konsumen mempunyai niat untuk membeli produk halal karena berbagai alasan. Niat membeli banyak digunakan dalam memahami perilaku konsumen yang sebenarnya.

\section{Religiostik dan Attitude.}

Secara khusus, dalam masyarakat Muslim, memahami bagaimana religiostik memengaruhi perilaku mereka sangat penting karena memainkan peran penting dalam hampir semua dimensi kehidupan Muslim, termasuk perilaku konsumsi (Sharma, Newaz, \& Fam, 2016). Religiostik mengacu pada tingkat komitmen seseorang terhadap ajaran dan hal itu menunjukkan bahwa hal itu sangat terkait dengan sikap, yang senada dengan Teori Fishbein dan Ajzen yang berpendapat bahwa sikap mengacu pada tingkat pengaruh untuk atau terhadap suatu objek. Lebih lanjut, Religiostik memegang peranan penting dalam perilaku seseorang karena dianggap sebagai salah satu faktor yang menentukan perilaku individu dan dianggap sebagai variabel fundamental yang berpengaruh terhadap sikap dan perilaku (Mukhtar \& Butt, 2012). Ketika individu percaya bahwa menggunakan kosmetik halal adalah bagian dari kewajiban dalam praktik keagamaan, ikap positif mereka secara keseluruhan terhadap produk kosmetik halal secara teoritis akan menguntungkan.

Agama membentuk perilaku masyarakat dan dapat mempengaruhi sikap dan perilaku masyarakat (Abu-Alhaija, Yusof, Hashim, \& Jaharuddin, 2018). (Mukhtar \& Butt, 2012) melaporkan bahwa Religiostik berperan dalam perilaku dan sikap konsumen terhadap pembelian barang dan jasa. Religiostik menjadi penentu kognisi dan perilaku individu. Dengan demikian, anggapan bahwa religiostik merupakan faktor krusial dalam perilaku konsumen Muslim dirasa tepat. Hasil penelitian (Abd Rahman, Asrarhaghighi, \& Ab Rahman, 2015) menyebutkan bahwa terdapat pengaruh yang signifikan antara religiostik dan attitude. Dari kacamata teori reasoned action (TRA) menunjukkan terdapat hubungan positif antara sikap dan niat memilih produk kosmetik halal. Hasil serupa juga dihasilkan oleh (Suparno, 2020) yang menyatakan bahwa Religiostik berpengaruh terhadap Cognitive attitude dan Affective Attitude.

Studi sebelumnya menggambarkan bahwa perilaku konsumen dengan religiusitas tinggi akan berbeda dari konsumen yang memiliki level rendah (Abu-Alhaija et al., 2018). Hal yang sama berlaku dalam penelitian konsumsi kosmetik halal. Sebagai Muslim makan berdasarkan ajaran Islam, tingkat religiusitas mereka mengatur perilaku muslim, termasuk cara mengonsumsi produk Halal. Peran religiusitas berpengaruh signifikan terhadap sikap (attitude) konsumen dalam mengonsumsi barang yang halal seperti (Amalia et al., 2020; Garg \& Joshi, 2018; Hanafiah \& Hamdan, 2020; Handriana et al., 2020; Ngah et al., 2020; Suparno, 2020). Religiusitas dapat mempengaruhi sikap dan minat beli terhadap produk Halal. Temuan ini diperkuat dengan (Shahid, Ahmed, \& Hasan, 2018). Religiusitas menawarkan dorongan yang kuat bagi umat Islam untuk selalu bertindak selaras dengan nilai dan norma Islam Sementara religiusitas dapat menentukan niat membeli ini 
diperkuat dengan penelitian sebelumnya (Amalia et al., 2020; Khan, Sarwar, et al., 2020; Mukhtar \& Butt, 2012) di mana membeli produk halal adalah sarana untuk mengekspresikan dan menjunjung tinggi religius mereka.

Berdasarkan paparan di atas, hipotesis penelitiannya :

H1 : Religiostik berpengaruh positif terhadap Attitude

H2 : Religiostik berpengaruh positif terhadap Purchase Intention

\section{Brand Image terhadap Attitude}

Konsep brand image telah menarik perhatian praktisi dan akademisi karena memengaruhi banyak hasil pemasaran. (Kotler \& Keller, 2016)mengemukakan merek dapat mempermudah proses dalam mengambil keputusan konsumen. Brand image adalah jumlah total asosiasi merek yang diadakan dalam ingatan konsumen yang menimbulkan persepsi tentang merek (Chinomona, 2016). Brand image merupakan gambaran mental konsumen tentang persembahan dan makna simbolik oleh konsumen terkait dengan atribut tertentu dari suatu produk. Kotler dan Amstrong (2012) mendefinisikan sikap sebagai pendekatan yang relatif konsisten dalam menggambarkan penilaian, perasaan, dan kecenderungan seseorang untuk suatu objek atau ide. Brand image merupakan persepsi tentang suatu merek dicerminkan dalam asosiasi merek yang ada di benak konsumen. Ketika konsumen mengalami kesulitan dalam membedakan tawaran dari pesaing berdasarkan kualitas nyata suatu produk, pemasar akan menggunakan citra merek sebagai senjata untuk memikat hati konsumen.

Bagi konsumen, sebuah merek akan menjadi salah satu pertimbangan konsumen dalam sikap berperilaku terhadap produk halal. Kesukaan atau ketidaksukaan konsumen terhadap suatu produk menjadi faktor penting dalam memahami sikap perilaku konsumen. Brand image yang baik akan mengarahkan sikap konsumen pada produk halal. Temuan studi yang dilakukan oleh (Elseidi \& El-baz, 2016; Handriana et al., 2020; Kim \& Kwon, 2018; Mazloomi, Sattari, \& Ebrahimpour, 2015) menyebutkan brand image memiliki pengaruh terhadap attitude konsumen terhadap produk.

Hipotesis :

\section{H4 : Brand Image berpengaruh positif terhadap Attitude \\ H4 : Brand Image berpengaruh positif terhadap Purchase Intention}

besar-besaran, karena perubahan teknologi yang sangat pesat dan penyebaran internet yang luas yang memudahkan konsumen untuk berbagi saran. Dengan demikian internet membawa sumber komunikasi yang kurang personal namun universal disebut elektronik dari mulut ke mulut. Studi menunjukkan bahwa semakin umum di antara konsumen ketika mengumpulkan informasi prapembelian untuk mempertimbangkan ulasan produk online (Adjei et al., 2009; Zhunand Zhang, 2010), yang tidak hanya bervariasi dalam konten tetapi juga dalam polaritas mereka dari positif ke negatif. komentar (Liu 2006; Sparks and Browning, 2011).

Online review memengaruhi hasil evaluasi produk oleh konsumen. Sikap negatif maupun positif terhadap suatu merek adalah hasil evaluasi preferensi pada suatu merek (Kumar, 2017). Sikap ketidaksukaan atau kesukaan konsumen terhadap sebuah merek bergantung dengan umlah review negatif dan positif pada merek tersebut (Yunus, Ariff, Som, Zakuan, \& Sulaiamn, 2016). Individu mengembangkan sikap berdasarkan evaluasi nilai dan keyakinan. Penerimaan atas informasi positif yang disediakan oleh komunikasi $e$-WOM akan pengaruh pada perkembangan sikap yang nantinya mengarah pada produk rekomendasi yang paling disukai dalam pembicaraan $e$-WOM (Hamouda \& Tabbane, 2013). Beberapa peneliti mengkonfirmasikan bahwa e-WOM mempunyai pengaruh yang positif terhadap attitude adalah (Doosti, Jalilvand, Asadi, Khazaei Pool, \& Mehrani Adl, 2016; Gosal, Andajani, \& Rahayu, 2020; Jalilvand, Ebrahimi, \& Samiei, 2013a; Kumar, 2017; Reza Jalilvand, Samiei, Dini, \& Yaghoubi Manzari, 2012; Zarrad \& Debabi, 2015). Dampak dari jumlah komentar online pada purchase intention menyimpulkan bahwa jumlah komentar online memiliki pengaruh pada niat membeli. Studi yang berhubungan dengan komunikasi EWOM menunjukkan bahwa itu bisa memiliki pengaruh yang besar pada niat beli konsumen berdsarkan informasi yang dikumpulkan dari EWOM dapat memengaruhi niat membeli produk. Beberapa penelitian yang menyimpulkan bahwa E-WOM berpengaruh terhadap purchase intention adalah (Elseidi \& AlBaz, 2016; Hamouda \& Tabbane, 2013; Jalilvand \& Samiei, 2012).

Hipotesis :

H5 : $E$-WOM berpengaruh positif terhadap Attitude

H6 : E-WOM berpengaruh positif terhadap Purchase intention

\section{E-Wom terhadap Attitude \\ Saat ini, bagaimana konsumen berinteraksi satu sama lain telah berubah secara}




\section{Attitude terhadap Purchase Intention}

Attitude adalah ringkasan evaluatif yang relatif permanen tentang suatu produk, yang penting karena memengaruhi dan memprediksi banyak perilaku. Attitude sebagai faktor pertama dalam TPB, attitude mengacu pada evaluasi individu terhadap perilaku tertentu, yang bisa berbentuk positif atau negatif (Fishbein \& Ajzen, 2011). Attitude mendefinisikan sikap sebagai keadaan pikiran yang mampu melakukan pengaruh langsung atau tidak langsung pada respons seseorang terhadap situas dan obyek yang terkait. Attitude merupakan suatu perilaku yang merupakan sejauh mana seseorang memiliki penilaian atau evaluasi yang menguntungkan dari perilaku tersebut. Secara umum, semakin disukai sikap terhadap suatu perilaku, semakin kuat niat individu untuk melakukan perilaku tersebut. Ada dua jenis attitude yang dapat dikenali, yaitu sikap terhadap perilaku dan sikap terhadap obyek (Handriana et al., 2020). Penelitian ini difokuskan pada sikap terhadap obyek (produk kosmetik korea) sedangkan behavioral intention merupakan salah satu tahapan yang akan dilalui konsumen dalam proses pembelian suatu produk. Menurut (Handriana et al., 2020) bahwa terdapat pengaruh yang positif antara kedua variabel tersebut menunjukkan bahwa sikap terhadap produk yang positif menghasilkan niat yang tinggi untuk membeli kosmetik halal pada konsumen wanita milenial muslim. Oleh karena itu, dengan sikap positif terhadap suatu produk kosmetik sangat mungkin konsumen akan melakukan pembelian kosmetik halal tersebut.

(Ngah et al., 2020) menyatakan bahwa dengan bersikap positif, konsumen muslim meyakini bahwa produk halal bermanfaat bagi mereka untuk menjaga kualitas halal produk halal. Oleh karena itu, untuk meningkatkan sikap tersebut, para pembuat kebijakan, penyedia produk halal dan departemen pemasaran produsen halal harus merancang program edukasi atau iklan yang mendidik dan menjelaskan manfaat produk halal dalam menjaga kualitas halal produknya. Temuan ini sejalan dengan (Iranmanesh et al., 2019) yang menyatakan bahwa attitude merupakan prediktor signifikan niat untuk membeli pada konsumen muslim untuk makanan bersertifikat halal. Artinya, jika umat Islam menganggap bahwa mengonsumsi makanan halal itu bermanfaat dan penting, maka attitude positif akan memotivasi konsumen untuk membayar lebih mahal untuk membeli makanan bersertifikat halal.

Studi yang dilakukan oleh (Aji, Muslichah, \& Seftyono, 2020; Amalia et al., 2020; Aziz, Md Husin, Hussin, \& Afaq, 2019; Bashir, 2019; Hanafiah \& Hamdan, 2020; Handriana et al., 2020; Jalilvand, Ebrahimi, \& Samiei, 2013b;
Jumani \& Sukhabot, 2020; Suparno, 2020; Wibowo et al., 2020; Zarrad \& Debabi, 2015) menunjukkan bahwa sikap konsumen memengaruhi niat konsumen untuk membeli produk. Konsumen yang memiliki sikap yang baik terhadap produk kosmetik halal cenderung akan membeli produk tersebut.

Hipotesis :

H7: Attitude berpengaruh positif terhadap Purchase Intention

\section{METODE PENELITIAN}

Populasi yang diambil dalam penelitian ini adalah konsumen yang mengetahui skincare asal Korea Selatan. Pemilihan kosmetik asal Korea Selatan di karenakan bahwa berdasarkan Survei dari survei ZAP Beauty Index 2020 terhadap mengungkapkan bahwa negara Korea Selatan yang masih menjadi negara dengan produk skincare yang diminati oleh wanita Indonesia $(57,6 \%)$, diikuti Indonesia $(37,4 \%)$ dan Jepang $(22,7 \%)(Z A P, 2020)$. Metode purposive sampel yang digunakan dalam penelitian ini. Sampel penelitian ini adalah konsumen muslim yang mengetahui skincare yang berasal dari Korea yaitu merek Etude House, Innisfree Laneige dan Nature Republic (Tirto.id, 2017).

Besarnya sampel diambil menggunakan perbandingan dari (Hair, Black, Babin, \& Anderson, 2010) di mana perbandingan menggunakan parameter 1:10 yaitu pada setiap satu pernyataan variabel penelitian mewakili 10 responden. Sehingga dengan banyaknya pernyataan sejumlah 20 pernyataan, maka sampel minimum yang diperlukan adalah sejumlah 200 responden, tetapi untuk menghindari pengurangan data dan meningkatkan keakuratan data, maka kuesioner yang disebarkan sebanyak 320 kuesioner. Jumlah kuesioner penelitian adalah 320 responden dengan teknik purposive sample.

Variabel Religiosity diadopsi dari pernyataan (Abd Rahman et al., 2015) yang terdiri dari 5 pernyataan. Variabel Brand Image diadopsi dari pernyataan (Jalilvand \& Samiei, 2012) yang terdiri dari 3 pernyataan. Variabel Ewom diadopsi dari pernyataan (Jalilvand \& Samiei, 2012) yang terdiri dari 6 pernyataan Variabel Attitude diadopsi dari pernyataan (Abd Rahman et al., 2015) yang terdiri dari 3 pernyataan Variabel Purchase intention diadopsi dari pernyataan (Kudeshia \& Kumar, 2017) yang terdiri dari 3 pernyataan. Skala pengukuran menggunakan skala likert 5 point.

\section{PEMBAHASAN}

Structural Equation Modeling (SEM) berbasis Partial Least Square (PLS) yang di gunkan dalam penelitian ini. PLS-SEM adalah metode alternatif model persamaan struktural 
untuk menguji hubungan antar konstruk laten dalam hubungan linear ataupun non linear dengan banyak indikator secara simultan. (Hair, Babin, Anderson, \& Black, 2018).

Pada Tabel 1 dapat dilihat bahwa semua item variabel adalah valid karena nilai loading faktor lebih besar dari 0,5 dan AVE lebih besar dari 0,5 ((Ghozali \& Latan, 2015)). Selain itu nilai Cronbach's Alpha juga lebih besar dari 0,5 dan nilai Composit Reability juga lebih besar dari 0,7 maka dapat disimpulkan bahwa semua variabel penelitian adalah realiabel (Ghozali \& Latan, 2015)

\begin{tabular}{|c|c|c|c|}
\hline Variabel & Indikator & $\begin{array}{c}\text { Loading } \\
\text { Faktor } \\
\end{array}$ & AVE \\
\hline \multirow{3}{*}{ Attitude } & Att1 & 0,684 & \multirow{3}{*}{0,607} \\
\hline & Att2 & 0,835 & \\
\hline & Att3 & 0,808 & \\
\hline \multirow{3}{*}{ Brand Image } & Bi1 & 0,868 & \multirow{3}{*}{0,788} \\
\hline & $\mathrm{Bi} 2$ & 0,904 & \\
\hline & $\mathrm{Bi} 3$ & 0,833 & \\
\hline \multirow{6}{*}{$E-W O M$} & Ewom1 & 0,656 & \multirow{6}{*}{0,531} \\
\hline & Ewom2 & 0,768 & \\
\hline & Ewom3 & 0,831 & \\
\hline & Ewom4 & 0,656 & \\
\hline & Ewom5 & 0,658 & \\
\hline & Ewom6 & 0,778 & \\
\hline \multirow{5}{*}{ Religiostik } & Rel1 & 0,958 & \multirow{5}{*}{0,679} \\
\hline & Rel2 & 0,612 & \\
\hline & Rel3 & 0,962 & \\
\hline & Rel4 & 0,514 & \\
\hline & Rel5 & 0,952 & \\
\hline \multirow{3}{*}{$\begin{array}{l}\text { Purchase } \\
\text { Intention }\end{array}$} & Pil & 0,729 & \multirow{3}{*}{0,633} \\
\hline & Pi2 & 0,808 & \\
\hline & Pi3 & 0,844 & \\
\hline
\end{tabular}

Sumber : data diolah (2020)

Selain itu pada Tabel 2 nilai Cronbach's Alpha juga lebih besar dari 0,5 dan nilai Composite Reability juga lebih besar dari 0,7 maka dapat di simpulkan bahwa semua variabel penelitian adalah reliabel ((Ghozali \& Latan, 2015)

Tabel 2 Hasil Uji Reliabilitas

\begin{tabular}{lcc}
\hline \multicolumn{1}{c}{ Variabel } & $\begin{array}{c}\text { Cronbach's } \\
\text { Alpha }\end{array}$ & $\begin{array}{c}\text { Composit } \\
\text { Reability }\end{array}$ \\
\hline Attitude & 0,67 & 0,821 \\
Brand Image & 0,923 & 0,897 \\
E-WOM & 0,824 & 0,87 \\
Religiostik & 0,861 & 0,908
\end{tabular}

ISSN: 2355-0295, e-ISSN: 2528-2255

http://ejournal.bsi.ac.id/ejurnal/index.php/ecodemica
Purchase

0,708

0,837

Sumber : data diolah (2020)

Dari gambar 2 terlihat hasil Analisa dengan menggunakan PLS .

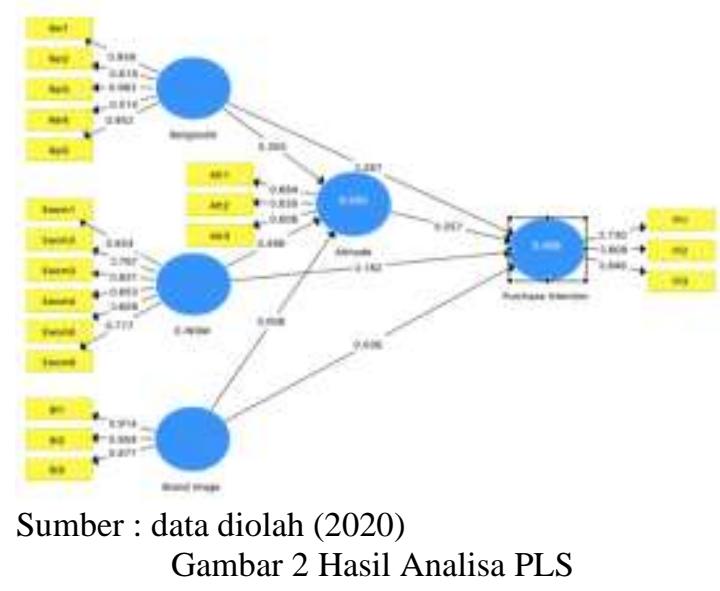

Dari Tabel 3 tentang uji hipotesis maka dapat disimpulkan bahwa semua hipotesis diterima kecuali hipotesis H3 dan H4. Hal ini dikarenakan pada $\mathrm{H} 3$ dan $\mathrm{H} 4$ hasil pengujian $P$-Value lebih dari 0,05 dan nilai T-statistics kurang dari 1,96 maka kedua hipotesis ditolak.

\begin{tabular}{lrrr}
\multicolumn{4}{c}{ Tabel 3 Hasil Uji Hipotesis } \\
\hline Hipotesis & $\begin{array}{c}\text { Path } \\
\text { Coefisien }\end{array}$ & P Values & $\begin{array}{c}\text { T- } \\
\text { Statistic }\end{array}$ \\
\hline H1 & 0,304 & 0,000 & 5,146 \\
H2 & 0,264 & 0,003 & 2,989 \\
H3 & 0,007 & 0,895 & 0,132 \\
H4 & 0,041 & 0,505 & 0,667 \\
H5 & 0,492 & 0,000 & 8,008 \\
H6 & 0,183 & 0,046 & 1,999 \\
H7 & 0,259 & 0,001 & 3,441 \\
\hline
\end{tabular}

Sumber: data diolah (2020)

Pada $\mathrm{H} 1$ yang menyatakan religiostik berpengaruh terhadap attitude dapat diterima pada penelitian ini. Hal ini dikarenakan nilai pengujian $P$-Value kurang dari 0,05 dan nilai T-statistics lebih dari 1,96. Hal ini dikarenakan bahwa keyakinan agama memengaruhi sikap terhadap produk kosmetik. Keyakinan beragama menjadi pedoman bagi umat Islam dalam kehidupannya termasuk dalam cara konsumsi(Yasid, Farhan, \& Andriansyah, 2016). Agama membentuk perilaku masyarakat dan dapat memengaruhi sikap dan perilaku konsumen. Tingkat kepercayaan masyarakat mengarahkan untuk menyukai atau tidak menyukai produk kosmetik halal. Temuan dalam penelitian ini menunjukkan bahwa semakin tinggi keyakinan agama maka semakin baik pula sikap konsumen terhadap produk kosmetik halal. Temuan penelitian ini mendukung penelitian yang 
dilakukan oleh (Amalia et al., 2020; Garg \& Joshi, 2018; Hanafiah \& Hamdan, 2020; Handriana et al., 2020; Ngah et al., 2020; Suparno, 2020).

Pada $\mathrm{H} 2$ menyebutkan bahwa religiostik berpengaruh terhadap purchase intention pada produk kosmetik dapat di terima pada penelitian ini. Hal ini dikarenakan nilai pengujian $P$-Value kurang dari 0,05 dan nilai T-statistics lebih dari 1,96. Hal ini terjadi karena konsumen yang memiliki religiostik yang tinggi akan mempunyai dorongan yang kuat untuk mementukan minat membeli pada produk kosmetik yang halal. Karena religiostik menawarkan dorongan yang kuat bagi umat Islam untuk selalu bertindak selaras dengan nilai dan norma Islam Sementara religiusitas dapat menentukan niat membeli ini diperkuat dengan penelitian sebelumnya (Amalia et al., 2020; Khan, Sarwar, et al., 2020; Mukhtar \& Butt, 2012) di mana membeli produk halal adalah sarana untuk mengekspresikan dan menjunjung tinggi religius mereka.

Pada H3 yang menyatakan bahwa brand image berpengaruh terhadap attitude, dan $\mathrm{H} 4$ yang berbunyi brand image berpengaruh terhadap purchase intention. Kedua hipotesis ini adalah ditolak karena hasil pengujian $P$-Value lebih dari 0,05 dan nilai $T$-statistics kurang dari 1,96 . Hal ini dikarenakan bahwa brand image tidak berpengaruh terhadap attitude dan purchase intention. Hal ini dikarenakan image suatu produk tidak membuat konsumen menjadi tertarik untuk membeli produk kosmetik. Pada H5 sejalan dengan penelitian (Sutiyati, Welsa, \& Lukitaningsih, 2020) yang menyatakan bahwa brand image tidak berpengaruh signifikan terhadap buying interest (minat beli).

Pada H5 yang menyatakan bahwa EWOM berpengaruh terhadap attitude pada penelitian ini adalah diterima. Hal ini dikarenakan nilai pengujian $P$-Value kurang dari 0,05 dan nilai T-statistics lebih dari 1,96 . Hal ini berarti bahwa review produk kosmetik online konsumen lain untuk mengetahui produk kosmetik apa yang memberikan kesan baik pada orang lain maka akan menimbulkan attitude terhadap produk kosmetik. Sikap terhadap produk kosmetik itu dipengaruhi oleh online review. Sikap ketidaksukaan atau kesukaan konsumen terhadap sebuah merek bergantung dengan jumlah review pada kosmetik tersebut. Individu mengembangkan sikap berdasarkan evaluasi nilai dan keyakinan. Penerimaan atas informasi dalam komunikasi $e$ WOM akan pengaruh pada perkembangan sikap yang nantinya mengarah pada produk rekomendasi yang paling disukai dalam pembicaraan $e$-WOM (Hamouda \& Tabbane, 2013). Hasil penelitian ini sesuai dengan (Doosti et al., 2016; Gosal et al.,
2020; Jalilvand et al., 2013a; Kumar, 2017; Reza Jalilvand et al., 2012; Zarrad \& Debabi, 2015).

Pada H6 menyebutkan bahwa E-WOM berpengaruh terhadap purchase intention, pada penelitian ini diterima. Hal ini dikarenakan nilai pengujian $P$-Value kurang dari 0,05 dan nilai $T$ statistics lebih dari 1,96. Dengan demikian sebelum terjadi pembelian maka konsumen akan mencari atau mengumpulakn informasi yang diperoleh dari review online dari produk kosmetik sehingga EWOM sangat berpengaruh terhadap purchase intention. Hasil penelitian ini sesuai dengan penelitian dari (Elseidi \& Al-Baz, 2016; Hamouda \& Tabbane, 2013; Jalilvand \& Samiei, 2012).

Pada H7 yang menyatakan bahwa attitude berpengaruh terhadap purchase intention, pada penelitian ini diterima. Hal terjadi karena sikap terhadap produk yang positif menghasilkan niat yang tinggi untuk membeli kosmetik halal pada konsumen wanita milenial muslim. Oleh karena itu, dengan sikap positif mereka terhadap suatu produk kosmetik sangat mungkin mereka akan melakukan pembelian kosmetik halal tersebut. Hasil penelitian ini sejalan dengan penelitian (Aji et al., 2020; Amalia et al., 2020; Aziz et al., 2019; Bashir, 2019; Hanafiah \& Hamdan, 2020; Handriana et al., 2020; Jalilvand et al., 2013b; Jumani \& Sukhabot, 2020; Suparno, 2020; Wibowo et al., 2020; Zarrad \& Debabi, 2015).

\section{PENUTUP}

Pada penelitian yang dilakukan dapat disimpulkan bahwa religiostik memengaruhi attitude dan purchase intention, EWOM berpengaruh terhadap attitude dan purchase intention, dan attitude berpengaruh terhadap purchase intention. Temua lain dari penelitian ini adalah brand image tidak berpengaruh terhadap attitude dan purchase intention.

Berdasarkan hasil penelitian ini hendaknya para produsen kosmetik harus memperhatikan $E$-WOM dan religiostik. Untuk itu pihak produsen kosmetik hendaknya menggunakan sosial media untuk dapat membuat postingan sedemikian sehingga menarik agar dapat meningkatkan partisipasi pembaca. Selanjutnya agar senantiasa mengupdate informasinya. Di samping itu adanya sertifikat halal untuk produk kosmetik nya. Untuk peneliti selanjutnya menambahkan variabel promosi karena menurut (Khan, Sarwar, et al., 2020) promosi mempengaruhi purchase intention. Diharapkan untuk menambahkan variabel satisfaction pada penelitian selanjutnya. 


\section{REFERENSI}

Abd Rahman, A., Asrarhaghighi, E., \& Ab Rahman, S. (2015). Consumers and halal cosmetic products: Knowledge, religiosity, attitude and intention. Journal of Islamic Marketing, $\quad 6(1)$, 148-163. https://doi.org/10.1108/JIMA-09-2013-0068

Abu-Alhaija, A. S. A., Yusof, R. N. R., Hashim, H., \& Jaharuddin, N. S. (2018). Religion in consumer behaviour research: the significance of religious commitment and religious affiliation. International Journal of Economics, Commerce and Management, 6(1), 245-258.

Ahmadova, E., \& Aliyev, K. (2020). Determinants of attitudes towards Halal products: Empirical evidence from Azerbaijan. Journal of Islamic Marketing. https://doi.org/10.1108/JIMA-04-2019-0068

Aji, H. M., Muslichah, I., \& Seftyono, C. (2020). The determinants of Muslim travellers' intention to visit non-Islamic countries: a halal tourism implication. Journal of Islamic Marketing. https://doi.org/10.1108/JIMA-032020-0075

Akın, M. S., \& Okumuş, A. (2020). Shaping the consumers' attitudes towards Halal food products in Turkey. Journal of Islamic Marketing. https://doi.org/10.1108/JIMA-082019-0167

Ali, A., Sherwani, M., Ali, A., Ali, Z., \& Sherwani, M. (2020). Investigating the antecedents of halal brand product purchase intention: an empirical investigation. Journal of Islamic Marketing. https://doi.org/10.1108/JIMA-03-2019-0063

Amalia, F. A., Sosianika, A., \& Suhartanto, D. (2020). Indonesian Millennials' Halal food purchasing: merely a habit? British Food Journal, 122(4), 1185-1198. https://doi.org/10.1108/BFJ-10-2019-0748

Aziz, S., Md Husin, M., Hussin, N., \& Afaq, Z. (2019). Factors that influence individuals' intentions to purchase family takaful mediating role of perceived trust. Asia Pacific Journal of Marketing and Logistics, 31(1), 81-104. https://doi.org/10.1108/APJML-12-20170311

Bashir, A. M. (2019). Effect of halal awareness, halal logo and attitude on foreign consumers' purchase intention. British Food Journal, 121(9), 1998-2015. https://doi.org/10.1108/BFJ-01-2019-0011

Chinomona, R. (2016). Brand communication, brand image and brand trust as antecedents of brand loyalty in Gauteng Province of South Africa. African Journal of Economic and Management Studies, VII(1). https://doi.org/10.1108/AJEMS-06-20160088

Doosti, S., Jalilvand, M. R., Asadi, A., Khazaei Pool, J., \& Mehrani Adl, P. (2016). Analyzing the influence of electronic word of mouth on visit intention: the mediating role of tourists' attitude and city image. International Journal of Tourism Cities, 2(2), 137-148. https://doi.org/10.1108/IJTC12-2015-0031

Elseidi, \& Al-Baz, D. (2016). Electronic word of mouth effects on consumers' brand attitudes, brand image and purchase intention: an empirical study in Egypt. The Business and Management Review, 7(5), 514-522. https://doi.org/10.1108/02634501211231946

Elseidi, R. I., \& El-baz, D. (2016). The effect of electronic word of mouth on brand image and purchase intention: An empirical study in the automobile industry in Iran. The Business and Management Review, 7(5), 514-522. https://doi.org/10.1108/02634501211231946

Fishbein, M., \& Ajzen, I. (2011). Predicting and Changing Behavior.

Garg, P., \& Joshi, R. (2018). Purchase intention of "Halal" brands in India: the mediating effect of attitude. Journal of Islamic Marketing, 9(3), 683-694. https://doi.org/10.1108/JIMA-11-2017-0125

Ghozali, I., \& Latan, H. (2015). Partial Least Squares : Konsep , Teknk dan Aplikasi Smart PLS 3.0. Badan Penerbit Universitas Diponegoro Semarang.

Gosal, J., Andajani, E., \& Rahayu, S. (2020). The Effect of e-WOM on Travel Intention, Travel Decision, City Image, and Attitude to Visit a Tourism City, 115(Insyma), 261-265. https://doi.org/10.2991/aebmr.k.200127.053

Hair, J. F., Babin, B. J., Anderson, R. E., \& Black, W. C. (2018). Multivariate data analysis (8th ed.). London: Cengage Learning EMEA.

Hair, J. F., Black, W. C., Babin, B. J., \& Anderson, R. E. (2010). Multivariate Data Analysis. Vectors. https://doi.org/10.1016/j.ijpharm.2011.02.01 9

Hamouda, M., \& Tabbane, R. S. (2013). Impact of Electronic Word of Mouth Evaluation on 
Purchase Intention: The Mediating Role of Attitude toward the Product. International Journal of Online Marketing, 3(June), 2037. https://doi.org/10.4018/ijom.2013040102

Hanafiah, M. H., \& Hamdan, N. A. A. (2020). Determinants of Muslim travellers Halal food consumption attitude and behavioural intentions. Journal of Islamic Marketing, 2. https://doi.org/10.1108/JIMA-09-2019-0195

Handriana, T., Yulianti, P., Kurniawati, M., Arina, N. A., Aisyah, R. A., Ayu Aryani, M. G., \& Wandira, R. K. (2020). Purchase behavior of millennial female generation on Halal cosmetic products. Journal of Islamic Marketing. https://doi.org/10.1108/JIMA-112019-0235

Haque, A., Anwar, N., Tarofder, A. K., Ahmad, N. S., \& Sharif, S. R. (2018). Muslim consumers' purchase behavior towards halal cosmetic products in Malaysia. Management Science Letters, 8(12), 1305-1318. https://doi.org/10.5267/j.msl.2018.9.009

Hu, X., Ha, L. H., Mo, S., \& Xu, Y. (2014). Who Are Fans of Facebook Fan Pages? an Electronic Word-of-Mouth Communication Perspective. International Journal of Cyber Society and Education, 7(2), 125-146. https://doi.org/10.7903/ijcse.1156

Indonesia. go.id. (n.d.). Agama. Retrieved from https://indonesia.go.id/profil/agama

Iranmanesh, M., Mirzaei, M., Parvin Hosseini, S. M., \& Zailani, S. (2019). Muslims' willingness to pay for certified halal food: an extension of the theory of planned behaviour. Journal of Islamic Marketing, 11(1), 14-30. https://doi.org/10.1108/JIMA03-2018-0049

Jalilvand, M. R., Ebrahimi, A., \& Samiei, N. (2013a). Electronic Word of Mouth Effects on Tourists' Attitudes Toward Islamic Destinations and Travel Intention: An Empirical Study in Iran. Procedia - Social and Behavioral Sciences, 81(2006), 484489.

https://doi.org/10.1016/j.sbspro.2013.06.465

Jalilvand, M. R., Ebrahimi, A., \& Samiei, N. (2013b). eWOM as Source of Influence: The Impact of Participation in eWOM and Perceived Source Trustworthiness on Decision Making. Procedia - Social and Behavioral Sciences, 81(2006), 484-489. https://doi.org/10.1016/j.sbspro.2013.06.465

Jalilvand, M. R., \& Samiei, N. (2012). The effect of electronic word of mouth on brand image and purchase intention: An empirical study in the automobile industry in Iran. Marketing Intelligence and Planning, 30(4), 460-476. https://doi.org/10.1108/02634501211231946

Jumani, Z. A., \& Sukhabot, S. (2020). Identifying the important attitude of Islamic brands and its effect on buying behavioural intentions among Malaysian Muslims: A quantitative study using smart-PLS. Journal of Islamic Marketing. https://doi.org/10.1108/JIMA-092019-0196

Karoui, S., \& Khemakhem, R. (2019). Factors affecting the Islamic purchasing behavior - a qualitative study. Journal of Islamic Marketing, 10(4), 1104-1127. https://doi.org/10.1108/JIMA-12-2017-0145

Kemenparin. (2020). Perubahan Gaya Hidup Dorong Industri Kosmetik.

Kemenperin. (2018). Industri Kosmetik Nasional Tumbuh $20 \%$.

Khan, Sarwar, A., \& Tan, B. C. (2020). Determinants of purchase intention of halal cosmetic products among Generation Y consumers. Journal of Islamic Marketing. https://doi.org/10.1108/JIMA-11-2019-0248

Khan, W., Akhtar, A., Ansari, S. A., \& Dhamija, A. (2020). Enablers of halal food purchase among Muslim consumers in an emerging economy: an interpretive structural modeling approach. British Food Journal, 122(7), 2273-2287. https://doi.org/10.1108/BFJ-082018-0528

Kim, S. B., \& Kwon, K. J. (2018). Examining the relationships of image and attitude on visit intention to Korea among Tanzanian college students: The moderating effect of familiarity. Sustainability (Switzerland), 10(2). https://doi.org/10.3390/su10020360

Kotler, P., \& Keller, K. (2016). Marketing management. Pearson Prentice Hall.

Kudeshia, C., \& Kumar, A. (2017). Social eWOM: does it affect the brand attitude and purchase intention of brands? Management Research Review, 40(3), 310-330. https://doi.org/10.1108/MRR-07-2015-0161

Kumar, C. kudeshia A. (2017). Social eWOM: Does it affect the brand attitude and purchase intention of brands? Management Resesarch Review, 40(3), 39. https://doi.org/10.1108/MRR-07-2015-0161

Lin, K. Y., \& Lu, H. P. (2011). Why people use social networking sites: An empirical study integrating network externalities and motivation theory. Computers in Human Behavior, 27(3), 1152-1161. https://doi.org/10.1016/j.chb.2010.12.009 
López, M., \& Sicilia, M. (2014). eWOM as Source of Influence: The Impact of Participation in eWOM and Perceived Source Trustworthiness on Decision Making. Journal of Interactive Advertising, 14(2), 86-97.

https://doi.org/10.1080/15252019.2014.9442 88

Mazloomi, A., Sattari, S., \& Ebrahimpour, H. (2015). Brand Loyalty , Brand Image Fitness , Final Brand Image Relationship with Attitude toward Brand at Tabarok and Delpazir Companies in Ahvaz City. Kuwait Chapter of Arabian Journal of Business and Management Review, 4(10), 11-15. https://doi.org/10.12816/0018992

Memon, Y. J., Azhar, S. M., Haque, R., \& Bhutto, N. A. (2019). Religiosity as a moderator between theory of planned behavior and halal purchase intention. Journal of Islamic Marketing. https://doi.org/10.1108/JIMA-012019-0006

Mirabi, V., Akbariyeh, H., \& Tahmasebifard, H. (2015). A Study of Factors Affecting on Customers Purchase Intention Case Study: the Agencies of Bono Brand Tile in Tehran. Journal of Multidisciplinary Engineering Science and Technology (JMEST), 2(1), 267-273.

Muflih, M., \& Juliana, J. (2020). Halal-labeled food shopping behavior: the role of spirituality, image, trust, and satisfaction. Journal of Islamic Marketing. https://doi.org/10.1108/JIMA-10-2019-0200

Muhamed, A. A., Ab Rahman, M. N., Mohd Hamzah, F., Che Mohd Zain, C. R., \& Zailani, S. (2019). The impact of consumption value on consumer behaviour: A case study of halal-certified food supplies. British Food Journal, 121(11), 2951-2966. https://doi.org/10.1108/BFJ-10-2018-0692

Mukhtar, A., \& Butt, M. M. (2012). Intention to choose Halal products: The role of religiosity. Journal of Islamic Marketing, $3(2)$, 108-120. https://doi.org/10.1108/17590831211232519

Ngah, A. H., Gabarre, S., Eneizan, B., \& Asri, N. (2020). Mediated and moderated model of the willingness to pay for halal transportation. Journal of Islamic Marketing. https://doi.org/10.1108/JIMA-10-2019-0199

Reza Jalilvand, M., Samiei, N., Dini, B., \& Yaghoubi Manzari, P. (2012). Examining the structural relationships of electronic word of mouth, destination image, tourist attitude toward destination and travel intention: An integrated approach. Journal of Destination Marketing and Management, 1(1-2), 134143.

https://doi.org/10.1016/j.jdmm.2012.10.001

Shahid, S., Ahmed, F., \& Hasan, U. (2018). A qualitative investigation into consumption of halal cosmetic products: the evidence from India. Journal of Islamic Marketing, 9(3), 484-503. https://doi.org/10.1108/JIMA-012017-0009

Sharma, R. R., Newaz, F. T., \& Fam, K. S. (2016). Muslim religiosity, generational cohorts and buying behaviour of Islamic financial products. Australian Journal of Management, 42(3), 482-501. https://doi.org/10.1177/0312896216659530

Shukla, P. (2011). Impact of interpersonal influences, brand origin and brand image on luxury purchase intentions: Measuring interfunctional interactions and a crossnational comparison. Journal of World Business, 46(2), 242-252. https://doi.org/10.1016/j.jwb.2010.11.002

Suhartanto, D., Dean, D., Sarah, I. S., Hapsari, R., Amalia, F. A., \& Suhaeni, T. (2020). Does religiosity matter for customer loyalty? Evidence from halal cosmetics. Journal of Islamic Marketing. https://doi.org/10.1108/JIMA-03-2020-0069

Suparno, C. (2020). Online purchase intention of halal cosmetics: S-O-R framework application. Journal of Islamic Marketing. https://doi.org/10.1108/JIMA-09-2019-0192

Sutiyati, Welsa, H., \& Lukitaningsih, A. (2020). Pengaruh Social Media dan Brand Image Terhadap Purchase Decision Melalui Buying Interest. Jurnal Ecodemica, 4(2), 264-274.

Tariq, M. I., Rafay Nawaz, M., Nawaz, M. M., \& Butt, H. A. (2013). Customer Perceptions about Branding and Purchase Intention: A Study of FMCG in an Emerging Market. $J$. Basic. Appl. Sci. Res, 3(2), 340-347.

Tirto.id. (2017). Indonesia, Target Pasar Seksi KBeauty di Asia.

Wibowo, M. W., Permana, D., Hanafiah, A., Ahmad, F. S., \& Ting, H. (2020). Halal food credence: do the Malaysian non-Muslim consumers hesitate? Journal of Islamic Marketing. https://doi.org/10.1108/JIMA-012020-0013

Yasid, Farhan, F., \& Andriansyah, Y. (2016). Factors affecting Muslim students awareness of halal products in Yogyakarta, Indonesia. 
International Review of Management and Marketing, 6(4), 27-31.

Yunus, N. H., Ariff, M. S. M., Som, N. M., Zakuan, N., \& Sulaiamn, Z. (2016). The Mediating Effect of Brand Image between Electronic Word of Mouth and Purchase Intention in Social Media. Advanced Science Letters, 22(10), 3176-3180. https://doi.org/10.1166/asl.2016.7999

ZAP, B. I. (2020). ZAP Beauty Index 2020.

Zarrad, H., \& Debabi, M. (2015). Analyzing the Effect of Electronic Word of Mouth on Tourists' attitude toward Destination and Travel Intention. International Research Journal of Social Sciences, 4(4), 2319-3565. https://doi.org/http://dx.doi.org/10.1159/000 093923

\section{BIODATA PENULIS}

Lily Purwianti adalah dosen Program Studi Manajemen Universitas Internasional Batam, fokus penelitian penulis antara lain Manajemen Pemasaran dan Strategik Manajemen 